\title{
Clinical genomics of the relationship between ADAMTS7 and coronary artery calcification and atherosclerosis
}

\author{
Simon W. Rabkin ${ }^{1}$, Pavlos G. Koitsopoulos ${ }^{2}$ \\ 1Division of Cardiology, Department of Medicine, University of British Columbia, Vancouver, BC V5Z 1M9, Canada.
}

${ }^{2}$ Faculty of Medicine, University of British Columbia, Vancouver, BC V5Z 1M9, Canada.

Correspondence to: Dr. Simon W. Rabkin, Division of Cardiology, Department of Medicine, University of British Columbia, Level 92775 Laurel St, Vancouver, BC V5Z 1M9, Canada. E-mail: simon.rabkin@ubc.ca

How to cite this article: Rabkin SW, Koitsopoulos PG. Clinical genomics of the relationship between ADAMTS7 and coronary artery calcification and atherosclerosis. J Trans/ Genet Genom 2018;2:4. https://doi.org/10.20517/jtgg.2018.01

Received: 6 Jan 2018 First Decision: 12 Mar 2018 Revised: 15 Mar 2018 Accepted: 21 Mar 2018 Published: 13 Apr 2018

Science Editor: Jian-Min Chen Copy Editor: Jun-Yao Li Production Editor: Huan-Liang Wu

\begin{abstract}
Aim: There are many coronary artery disease (CAD) cases in which the explanation for its development cannot be readily explained by traditional risk factors. The purpose of this study was to examine the data whether ADAMTS7 polymorphisms is related to the presence or severity of CAD.
\end{abstract}

Methods: A systematic review of the literature was conducted to address the relationship between ADAMTS7 polymorphism and atherosclerosis.

Results: Nine studies were evaluated that examined the relationship between ADAMTS7 and coronary atherosclerosis and 3 studies that examined the relationship between ADAMTS7 and coronary calcification. The single nucleotide polymorphs (SNPs) included rs3825807, rs79265682, rs1994016, rs4380028, for coronary atherosclerosis and rs7173743, rs3825807 and rs1994016 for coronary artery calcification. The most consistent evidence for an association with coronary artery stenosis on coronary angiogram was with ADAMTS7 rs3825807 risk allele A vs. control G, followed by rs4380028. ADAMTS7 SNP rs3825807 was consistently association with coronary artery calcification. ADAMTS7 was associated with CAD severity and adverse CAD prognosis.

Conclusion: ADAMTS7 polymorphisms especially SNP rs4380028 allele has been consistently associated with CAD with ADAMTS7 rsrs4380028 being the next most strongly associated. ADAMTS7 warrants further exploration for a role in the pathogenesis of CAD.

Keywords: ADAMTS7 polymorphisms, coronary artery calcification, coronary artery atherosclerosis, coronary artery disease

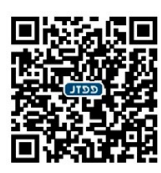




\section{INTRODUCTION}

Coronary artery disease (CAD) is the leading cause of morbidity and mortality in the developed world and is increasing in prevalence in low and middle income countries ${ }^{[1]}$. The traditional factors leading to atherosclerotic coronary artery disease - hypertension, dyslipidemia, diabetes mellitus and cigarette smoking, are well known and are subject to multiple risk factor intervention to reduce cardiovascular risk $^{[2]}$. There remain many CAD cases in which the explanation for the premature development of CAD or its accelerated progression cannot be readily accounted for by the traditional risk factors. It has long been recognized that genetic factors may account for a significant percentage of the inter-individual variation in the CAD and its progression ${ }^{[3]}$. More recently various genetic studies have identified genetic risk variants that may play a causative role in CAD development ${ }^{[4-6]}$. A number of allelic single nucleotide polymorph (SNP) variants show an increased risk of CAD, however most of these are related to known CAD risk factors specifically those related to lipid metabolism, blood pressure or arterial wall components that are known to produce atherosclerosis ${ }^{[6]}$. There is a need to examine novel factors that might lead to new strategies to prevent atherosclerotic coronary artery disease. One group of genetic factors that falls into this category is the ADAM (A Disintegrin And Metalloproteinases) family of genes and especially the ADAMTS (A Disintegrin And Metalloproteinase with ThromboSpondin motifs) family so named because it possesses the thrombospondin motif. Of the ADAMTS family members ADAMTS7 is of special interest.

The ADAMTS7 gene is located on chromosome 15: 78,759,203-78,811,431 and has 5 transcripts (splice variants), 79 orthologues, 10 paralogues, and is a member of a family that is associated with 67 phenotypes ${ }^{[7]}$. The gene product - ADAMTS7, is a 1686 amino acid protein which contains a signal peptide, a prodomain, a metalloproteinase domain, a disintegrin-like domain, and a thrombospondin type-1 motif $^{[8-10]}$. After cleavage of the prodomain, the activated proteolytic enzyme can be secreted and binds to proteins such as $\alpha 2$-macroglobulin, connective tissue growth factor and cartilage oligomeric matric protein $(\mathrm{COMP})^{[11]}$. ADAMTS7 has three main substrates COMP, progranulin, and alpha2macroglobulin ${ }^{[9]}$. ADAMTS7 is produced and secreted by macrophages. Following secretion and activation through cleavage of the prodomain, ADAMTS7 acts as proteolytic enzyme degrading the extracellular matrix of vessel walls most notably to cleave the vascular extracellular matrix protein thrombospondin-5 $(\mathrm{TSP} 5)^{[9,12,13]}$.

Animal data support the postulate that ADAMTS7 cleavage of TSP5 facilitates vascular smooth muscle cell migration and promotes neointimal formation which leads to $\mathrm{CAD}^{[13-15]}$. The question is whether the animal data is relevant to humans. There is a need to evaluate and determine whether there is consistent relationship in the genomic data specifically whether the ADAMTS7 locus is associated with coronary artery atherosclerotic vascular disease and specifically whether ADAMTS7 polymorphisms are linked to CAD. After synthesizing the data on the potential genomic associations, we will consider how ADAMTS7 is translated into clinical atherosclerotic coronary artery disease.

\section{METHODS}

A systematic review of the literature was conducted for the period 1946 through to November 30, 2017. The study objective was to summarize the genetic SNP missense mutations of ADAMTS7 and relate it to the presence and implications for CAD. MEDLINE (Ovid) was searched using the following key words explode ADAMTS7/, explode polymorphism, single nucleotide/AND explode coronary artery disease. Search results were limited to human studies and references were reviewed for additional studies. Studies with data on ADAMTS7 were examined in detail. The inclusion criteria for analysis were: (1) an original study; (2) published in English; (3) a human study; (4) radiologic, either computed tomography (CT) calcium or coronary angiographic confirmation of CAD defined as > 50\% stenosis; and (5) data reported on CAD outcomes. Studies were divided according to whether the data on coronary artery disease was based on 
Table 1. The relationship between ADTAMTS7 SNP and coronary atherosclerosis

\begin{tabular}{|c|c|c|c|c|c|c|}
\hline Authors & SNP & $\begin{array}{l}\text { Risk allele/ } \\
\text { other allele }\end{array}$ & Country/ethnicity & CAD & $\begin{array}{l}\text { No. of } \\
\text { cases }\end{array}$ & $\begin{array}{l}\text { No. of } \\
\text { controls }\end{array}$ \\
\hline \multirow[t]{2}{*}{ Chan et $\left.a\right|^{[18]}$} & \multirow[t]{2}{*}{ rs3825807 } & \multirow[t]{2}{*}{$\mathrm{A} / \mathrm{G}$} & UK & Angiographic CAD in the Southampton UK & 1076 & 283 \\
\hline & & & USA & Angiographic CAD in the Atlanta USA & 1710 & 974 \\
\hline You et $a / .{ }^{[19]}$ & rs3825807 & $A / G$ & $\begin{array}{l}\text { China } \\
\text { (Chinese Han group) }\end{array}$ & Coronary angiogram & 4002 & 4152 \\
\hline Assimes et al. ${ }^{[20]}$ & rs79265682 & $G / A$ & Taiwan & $\begin{array}{l}\text { CAD defined clinically or via angiographic } \\
\text { data of } 1 \text { vessel with }>50 \% \text { stenosis }\end{array}$ & 3133 & 5423 \\
\hline \multirow[t]{3}{*}{ Lu et al. ${ }^{[21]}$} & rs1994016 & $\mathrm{C} / \mathrm{T}$ & \multirow{3}{*}{$\begin{array}{l}\text { China } \\
\text { (Chinese Han group) }\end{array}$} & \multirow{3}{*}{$\begin{array}{l}\text { CAD defined by angiographic data showing } \\
\text { at least one vessel with }>50 \% \text { stenosis }\end{array}$} & \multirow[t]{3}{*}{1010} & \multirow[t]{3}{*}{3998} \\
\hline & rs3825807 & $A / G$ & & & & \\
\hline & rs4380028 & $\mathrm{C} / \mathrm{T}$ & & & & \\
\hline Dechamethakun et al. ${ }^{[22]}$ & rs4380028 & $A / G$ & Japan & CAD at autopsy & 1536 & \\
\hline Schunkert et al. ${ }^{[4]}$ & rs3825807 & $A / G$ & $\begin{array}{l}\text { Multi-country } \\
\text { European Ancestry }\end{array}$ & $\begin{array}{l}\text { CAD defined as either by angiographic and } \\
\text { clinical verification }\end{array}$ & 45,063 & 84,589 \\
\hline The CAD Consortium ${ }^{[23]}$ & rs4380028 & $\mathrm{C} / \mathrm{T}$ & $\begin{array}{l}\text { European and South } \\
\text { Asian }\end{array}$ & $\begin{array}{l}\text { CAD defined angiographically with } 1 \text { or more } \\
\text { vessels with }>50 \% \text { stenosis or clinically) CAD }\end{array}$ & 36,828 & 34,247 \\
\hline Reilly et al. ${ }^{[24]}$ & rs1994016 & $\mathrm{C} / \mathrm{T}$ & European Ancestry & Coronary angiographic CAD & 12,393 & 7383 \\
\hline
\end{tabular}

CAD: coronary atherosclerotic disease; SNP: single nucleotide polymorph

coronary artery calcification or coronary artery stenosis. Exclusion criteria were based on the following: (1) review articles without new data on SNP associated CAD; (2) abstracts from unpublished studies; and (3) case reports and letters. Additional studies identified by examination of the reference lists, were assessed using the same inclusion and exclusion criteria.

Meta-analyses of the aggregate data were conducted with the Review Manager (RevMan) software (Version 5.3.5. The Nordic Cochrane Centre, Copenhagen, Denmark ${ }^{[16]}$. From each entry, the study name, sample size, mean, and standard deviation were entered using the standard mean difference method. Randomeffects model was utilized to generate summary statistics. To assess heterogeneity, the Cochrane $Q$ statistic, $I^{2}$ statistic and Tau-squared statistic were calculated. Statistical significance was set as $P<0.05$ unless otherwise specified.

\section{RESULTS}

ADAMTS7 was related to CAD in 12 studies that were identified in our search strategy and are outlined using the PRISMA format ${ }^{[17]}$ [Figure 1].

The data was examined separately for those studies with coronary calcification versus studies with documented coronary atherosclerosis [Table 1 $]^{[4,18-24]}$.

\section{Coronary atherosclerosis}

Reilly et al. ${ }^{[24]}$ compared patients with angiographic CAD with controls and identified a significant association between ADAMTS7 SNP rs1994016, and angiographic CAD. In that study, there was no association with myocardial infarction ${ }^{[24]}$ suggesting two focuses for genetic control: one on the development of coronary atherosclerosis and the second on processes leading to myocardial infarction in the presence of coronary atherosclerosis. In another study, rs4380028 polymorphism in 8424 Europeans and 6996 South Asians and 15,062 controls was followed by an independent (replication) sample of 21,408 cases and 19,185 controls. The cases had a prior history of myocardial infarction or "symptomatic CAD" (angina) or coronary artery revascularization, with an average age at first event under 60 years. They found a significant association between $\mathrm{rs} 4380028$ and $\mathrm{CAD}^{[23]}$.

Dechamethakun et al. ${ }^{[22]}$ examined $\mathrm{rs} 4380028$ polymorphism (A/G) using a TaqMan ${ }^{\mathrm{R}}$ assay and the severity of coronary artery stenosis defined as sum of degrees of stenosis in left anterior descending circumflex 


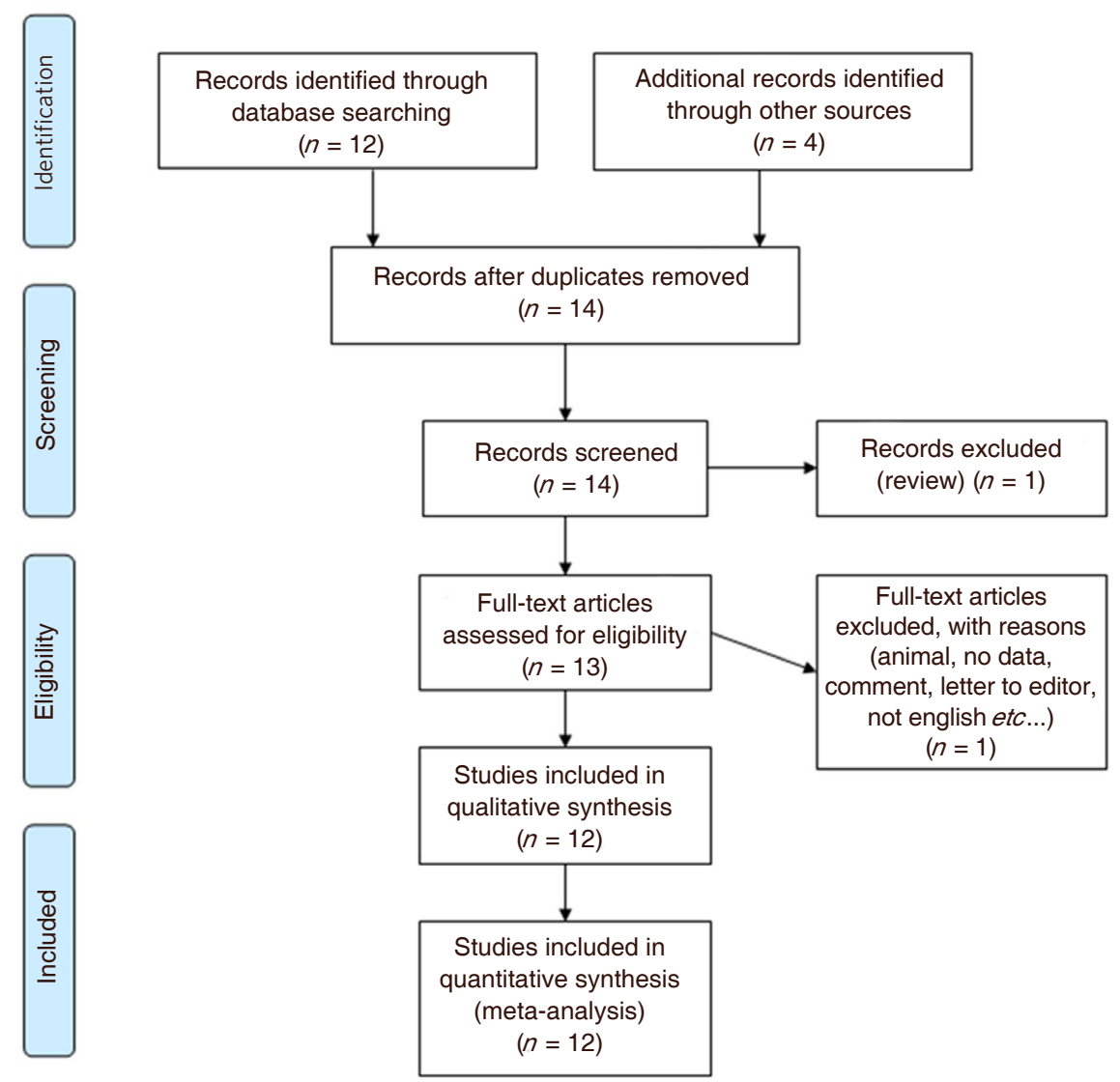

Figure 1. PRISMA flow chart outlining search strategy

and right coronary arteries in autopsies of 1535 elderly, mean age 80 years. They did not find a significant association between rs4380028 poly morphism and coronary stenosis severity [odds ratio (OR) 1.042; 95\% confidence interval (CI) $0.797-1.363]^{[22]}$.

Schunkert et al.$^{[4]}$ reported on genome-wide association studies of coronary artery disease comprising 22,233 cases and 64,762 controls of European descent, followed by genotyping of an addition 60,738 additional individuals. They found a significant association between rs3825807and $\mathrm{CAD}^{[4]}$.

Lu et al. ${ }^{[21]}$ carried out 2 genome-wide association studies comprising 1515 CAD cases and 5019 controls, followed by replication studies in 15,460 CAD cases and 11,472 controls, all of Chinese Han descent. They found a significant association of C/T polymorphism in rs4380028 and CAD but not with other alleles that they examined (see supplement) ${ }^{[21]}$.

Assimes et al ${ }^{[20]}$ genotyped 8556 subjects from Taiwan, consisting of 5423 controls and 3133 cases with coronary artery disease defined as having a history of myocardial infarction, percutaneous coronary intervention (PCI) or coronary artery bypass graft (CABG), or coronary artery stenosis of greater than $50 \%$. They used the CardioMetaboChip and concluded that rs1537372 accounts for all of the CAD association at the 9 p21 chromosomal locus ${ }^{[20]}$. They reported that ADAMTS7 specifically the G allele of rs79265682 was significantly associated with coronary artery disease $\mathrm{e}^{[20]}$.

You et al ${ }^{[19]}$ reported on two study populations (Shijiazhuang and Wuhan) in China with CAD and controls that were evaluated forthe association between the ADAMTS7 rs3825807 genotype and CAD. They found that ADAMTS7 rs3825807 was associated with susceptibility to CAD (OR 1.15; 95\% CI 1.05-1.26) ${ }^{[19]}$. 


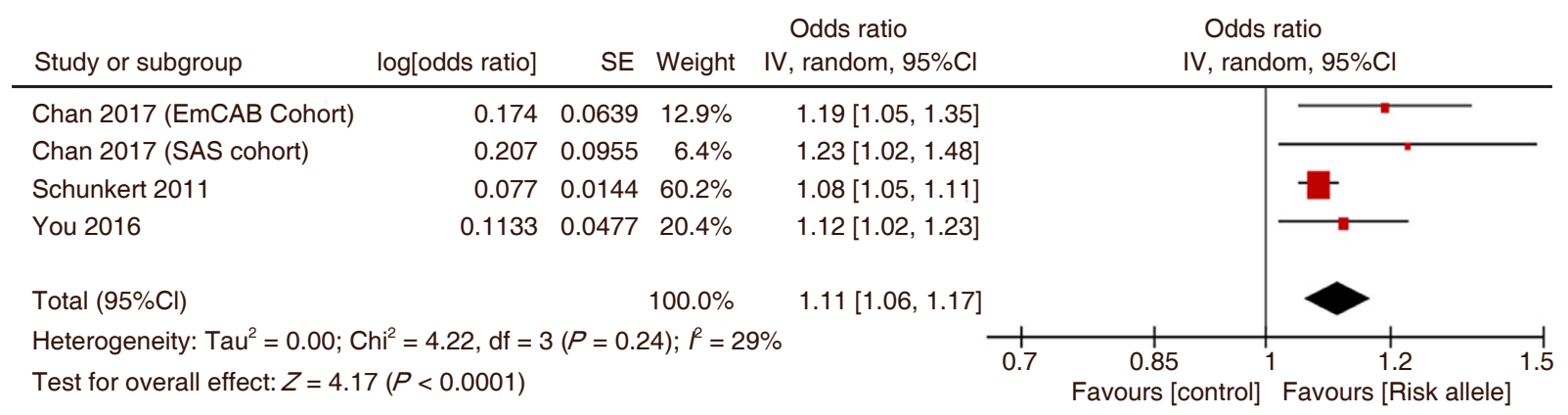

Figure 2. The Forest plot of the comparison of ADAMTS7 SNP rs3825807 risk allele A vs. control allele G and coronary atherosclerotic disease

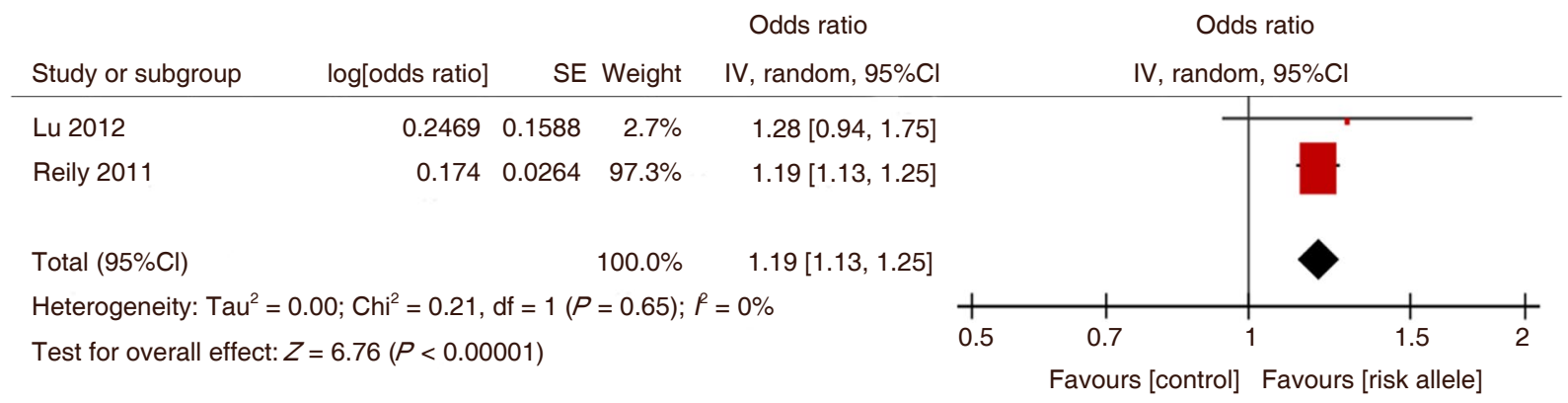

Figure 3. The Forest plot of the comparison of ADAMTS7 SNP rs1994016 risk allele C vs. control allele T and the association with coronary atherosclerotic disease

Chan et al. ${ }^{[18]}$ reported on the relationship between rs3825807 polymorphism and coronary stenosis found on coronary angiography in 2 cohorts, one in the UK and one in USA. They found G allele was associated with $16 \%$ to $19 \%$ lower odds of obstructive CAD in their Southampton Atherosclerosis Study group and Emory University cohorts ${ }^{[18]}$.

Meta-analysis of the SNPs on which there was repeated data showed that rs3825807 was consistently and significantly related to CAD [Figure 2]. When evaluating the strength of the association between the ADAMTS7 SNP rs3825807 risk allele A vs. G and the association with CAD, there was a significantly increased OR for the presence of CAD. The data from the two populations examined by Chan et al. ${ }^{[18]}$ were considered separately but in total they contributed only a small amount to the overall relationship between ADAMTS7 SNP rs3825807 and CAD [Figure 2]. The comparison of ADAMTS7 SNP rs1994016 risk allele $\mathrm{C} v$ s. control allele $\mathrm{T}$ demonstrated the association of the $\mathrm{C}$ allele with coronary atherosclerotic disease although the limited number of studies is a concern [Figure 3].

The data were analyzed including and excluding the autopsy study of Dechamethakun et al. ${ }^{[22]}$. It is reasonable to exclude this autopsy study because it was not consistent with all other studies that used coronary angiography. In addition, this autopsy study did not considered cases vs controls but rather as a liner correlation between the SNP the amount of CAD as assessed by a sum of atherosclerotic severity in all coronary arteries [Figure 4]. However its inclusion did not materially alter the overall conclusion that ADAMTS7 SNP rs4380028 significantly increases the odds ratio for the presence of CAD.

\section{Coronary artery calcification}

There were fewer studies that examined for coronary artery calcification (CAC) [Table 2] $]^{[25-27]}$.

O’Donnell et al. ${ }^{[27]}$ reported on genome-wide association studies for CAC in 9961 men and women from 5 independent community-based cohorts, with replication in 3 additional independent cohorts with 


\begin{tabular}{|c|c|c|c|c|c|c|c|c|}
\hline Study or subgroup & log[odds ratio] & SE & Weight & $\begin{array}{l}\text { Odds ratio } \\
\text { IV, random, } 95 \% \mathrm{Cl}\end{array}$ & \multicolumn{4}{|c|}{$\begin{array}{l}\text { Odds ratio } \\
\text { IV, random, } 95 \% \mathrm{Cl}\end{array}$} \\
\hline Dechamethakun 2014 & 0.0411 & 0.1368 & $6.4 \%$ & $1.04[0.80,1.36]$ & & & & \\
\hline Lu 2012 & 0.157 & 0.0394 & $35.5 \%$ & $1.17[1.08,1.26]$ & & & $=$ & \\
\hline Peden 2011 & 0.0677 & 0.0096 & $58.1 \%$ & $1.07[1.05,1.09]$ & & & & \\
\hline Total $(95 \% \mathrm{Cl})$ & & & $100.0 \%$ & $1.10[1.03,1.18]$ & & & & \\
\hline \multicolumn{5}{|c|}{$\begin{array}{l}\text { Heterogeneity: } \mathrm{Tau}^{2}=0.00 ; \mathrm{Chi}^{2}=4.90, \mathrm{df}=2(P=0.09) ; P=59 \% \\
\text { Test for overall effect: } Z=2.68(P=0.007)\end{array}$} & 0.7 & $\begin{array}{c}0.85 \\
\text { Favours [control] }\end{array}$ & Favours [risk allele] & $\overrightarrow{1.5}$ \\
\hline Study or subgroup & log[odds ratio] & SE & Weight & $\begin{array}{c}\text { Odds ratio } \\
\text { IV, random, } 95 \% \mathrm{Cl}\end{array}$ & & $\begin{array}{r}\text { Odds } \\
\mathrm{IV} \text {, randor }\end{array}$ & & \\
\hline Lu 2012 & 0.157 & 0.0394 & $40.8 \%$ & $1.17[1.08,1.26]$ & & & -1 & \\
\hline Peden 2011 & 0.0677 & 0.096 & $59.2 \%$ & $1.07[1.05,1.09]$ & & & & \\
\hline Total $(95 \% \mathrm{Cl})$ & & & $100.0 \%$ & $1.11[1.02,1.21]$ & & & & \\
\hline \multicolumn{5}{|c|}{$\begin{array}{l}\text { Heterogeneity: } \mathrm{Tau}^{2}=0.00 ; \mathrm{Chi}^{2}=4.85, \mathrm{df}=1(P=0.03) ; P^{2}=79 \% \\
\text { Test for overall effect: } Z=2.37(P=0.02)\end{array}$} & 0.7 & $\begin{array}{c}0.85 \\
\text { Favours [control] }\end{array}$ & $\begin{array}{cc}1.2 \\
\text { Favours [risk allele] }\end{array}$ & $\overrightarrow{1.5}$ \\
\hline
\end{tabular}

Figure 4. The Forest plot of the comparison of ADAMTS7 SNP rs 4380028 risk allele C vs. control allele T and the association with coronary atherosclerotic disease. The upper panel shows the data without and the lower panel shows the data with the study of Deschamethakun et al. ${ }^{[22]}$

most cohorts using different genotyping. Forty-eight SNPs located on chromosome 9p21 and 1 SNP on chromosome 6p24 attained genome-wide significance ${ }^{[27]}$. ADAMTS7 remained significant after Bonferroni adjustment and was only 1 of 7 SNPs that were associated with CAC after Bonferroni adjustment, including SNPs in $9 \mathrm{p} 21$ and $6 \mathrm{p} 24^{[27]}$. ADAMTS7 was not, however associated with premature onset of myocardial infarction in these cohorts ${ }^{[27]}$.

van Setten et al. ${ }^{[26]}$ reported on the examination of approximately 2.5 million SNPs for their association with coronary artery calcification and aortic calcification in 2620 male smoker who underwent chest CT scans. While no SNPs were associated with aortic calcification, the 9 p21 locus was significantly associated with coronary artery calcification. A missense change (Pro214 Ser) occurring at ADAMTS7 showed a significant association with coronary artery calcification ${ }^{[26]}$. After all individuals with zero Agatston scores were excluded and the analysis repeated, ADAMTS7 rs3825807, remained significantly associated with coronary artery calcification ${ }^{[26]}$

Vargas et al. ${ }^{[25]}$ reported on a study in the USA which examined gene associations in the Multi-Ethnic Study of Atherosclerosis that consisted of 8224 participants with different ethnic origins (2329 Caucasians, 691 Chinese, 2482 African Americans, and 2012 Hispanics. They reported that CAC was associated with SNPs in 9p21. In the Hispanic population, ADAMTS7 (rs7173743) was significantly associated with CAC ${ }^{[25]}$. Across all ethnic groups, however, neither rs7173743 or rs1994016 was associated with CAC $^{[25]}$.

There were only two separate studies that examined the association of CAC with an ADAMTS\& SNP and it was for rs3825807. The analysis showed a significant association between CAC and rs3825807 [Figure 5].

\section{Severity of CAD}

Chan et al ${ }^{[18]}$ found that the GG allele rs3825807 conferred a $16 \%$ lower rate of coronary artery disease, $15 \%$ lower rate of multivessel coronary artery disease and a $17 \%$ lower rate of LAD disease. In addition, they reported that rs3825807 was associated with less severe CAD as reflected in lower Gensini and lower Sullivan scores ${ }^{[18]}$.

\section{Outcome}

A cohort of 1128 patients with angiographic proven CAD, were genotyped for rs3825807 A/G and followed prospectively for a mean of 5.3 years ${ }^{[28]}$. The AA genotype was a significant independent risk factor for 
Table 2. The relationship between ADAMTS7 and CAC

\begin{tabular}{|c|c|c|c|c|c|c|c|}
\hline Authors & SNP & $\begin{array}{l}\text { Risk allele/ } \\
\text { other allele }\end{array}$ & $\begin{array}{l}\text { Country/ } \\
\text { ethnicity }\end{array}$ & CAC & Data & $\begin{array}{l}\text { No. of } \\
\text { cases }\end{array}$ & $\begin{array}{l}\text { No. of } \\
\text { controls }\end{array}$ \\
\hline \multirow[t]{2}{*}{ Vargas et al. ${ }^{[25]}$} & rs1994016 & $\mathrm{C} / \mathrm{T}$ & $\begin{array}{l}\text { USA } \\
\text { MultiEthnic }\end{array}$ & $\begin{array}{l}\text { CAC assessed via } \\
\text { Agatston method }\end{array}$ & $\begin{array}{l}\text { Comparison of risk allele } \\
\text { C association with in a } \\
\text { multiethnic population of } \\
\text { Caucasians, Asian, Afro- } \\
\text { Americans and Hispanic }\end{array}$ & 8224 & \\
\hline & rs7173743 & $\mathrm{C} / \mathrm{T}$ & & & $\begin{array}{l}\text { Comparison of risk allele C } \\
\text { association with CAC in a } \\
\text { Hispanic subgroup }\end{array}$ & 2012 & \\
\hline van Setten et al. ${ }^{[26]}$ & rs3825807 & $A / G$ & European & $\begin{array}{l}\text { CAC assessed via } \\
\text { Agatston method }\end{array}$ & $\begin{array}{l}\text { Comparison of risk allele } \\
\text { A association with CAC } \\
\text { assessed via Agatston } \\
\text { method }\end{array}$ & 2620 & \\
\hline O'Donnell et al. ${ }^{[27]}$ & rs3825807 & $A / G$ & European & $\begin{array}{l}\text { CAC assessed via } \\
\text { Agatston method }\end{array}$ & $\begin{array}{l}\text { Comparison of risk allele } \\
\text { A association with CAC } \\
\text { assessed via Agatston } \\
\text { method }\end{array}$ & $\begin{array}{l}\text { Discovery } \\
n=9961\end{array}$ & $\begin{array}{l}\text { Additional } \\
n=6032\end{array}$ \\
\hline
\end{tabular}

CAC: coronary artery calcification; SNP: single nucleotide polymorph

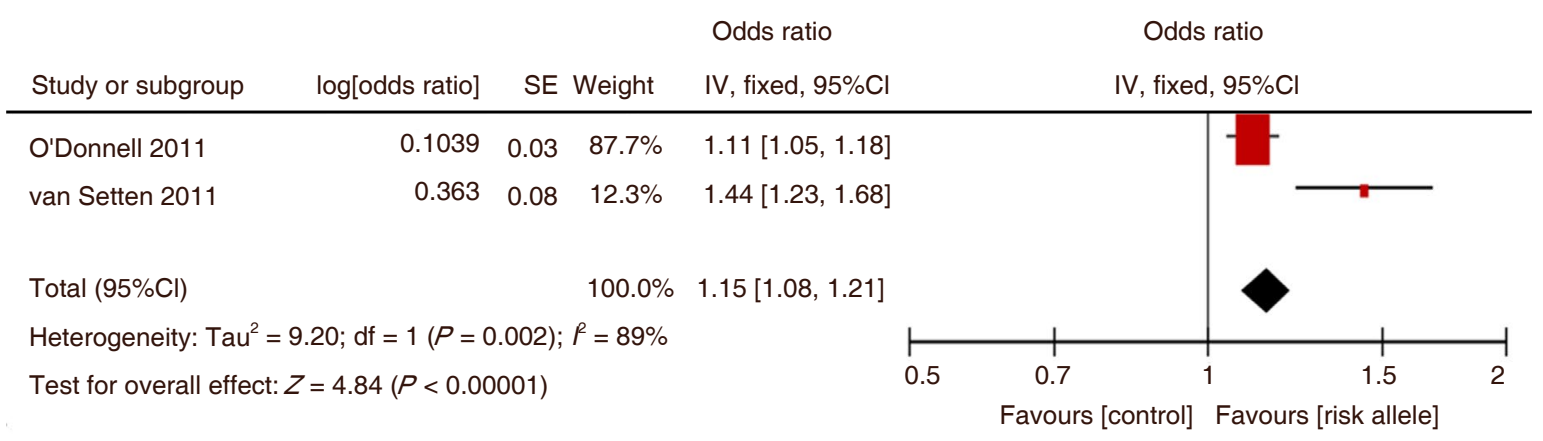

Figure 5. The Forest plot of comparison between the development of the coronary artery calcification and ADAMTS7 risk allele SNP rs3825807

cardiovascular mortality compared with the reference genotype GG (hazard ratio $=2.7)^{[28]}$. At the end of follow-up, the estimated survival was $89.8 \%$ for GG genotype, $82.2 \%$ for AG and $72.3 \%$ for AA genotype. Carriage of the mutant G allele of the ADAMTS7 gene was associated with improved cardiovascular survival when survival was assessed by Kaplan-Meir survival curves with the difference being apparent after about 70 months and persisted for the duration of follow-up which was about 168 months ${ }^{[28]}$. These data were confirmed by Chan et al. ${ }^{[18]}$ in a different cohort in a 3-year follow-up, in which the GG phenotype was associated with a significant lower risk of subsequent PCI or CABG.

\section{DISCUSSION}

This study has synthesized available knowledge, to date, on the relationship between ADAMTS7 polymorphism in humans and coronary artery disease. We found that ADAMTS7 was consistently related to coronary artery disease both coronary artery calcification and coronary artery stenosis identified by coronary angiography. The only exception to the general relationship was an autopsy study of elderly Japanese persons ${ }^{[22]}$. While it is reasonable to conclude that ADAMTS7 is a marker for early atherosclerosis and that other factors contribute to atherosclerosis in the elderly, that study did not alter the overall significant relationship between that SNP and the presence of CAD. We separately considered coronary artery disease identified by coronary artery calcification on CT and coronary stenosis by coronary angiography. Coronary calcification can be an earlier manifestation of coronary artery disease and is not equal to the degree of coronary stenosis produced by atherosclerosis that consists of different plaque components especially cholesterol ${ }^{[29]}$. Although the two conditions were examined separately, the results 
indicate that ADAMTS7 is associated with both conditions suggesting separate but complementary processes. The strongest relationship and consistent across two different studies was for rs3825807.

\section{Coronary artery calcification}

The data linking ADAMTS7 and coronary artery calcification is supported by other kinds of data. ADAMTS7 expression was upregulated and was associated with calcification of radial arteries of patients with chronic kidney disease and uremia ${ }^{[30]}$. ADAMTS7 expression is upregulated in calcified arteries of rats with chronic renal failure ${ }^{[30]}$. The data suggests that upregulation of this metalloproteinase mediates vascular smooth muscle calcification ${ }^{[30]}$. Supporting this concept is the data that miR-29a/b inhibits vascular smooth muscle cell (VSMC) calcification by suppressing ADAMTS7 expression ${ }^{[30]}$. The repression of miR-29a/b by risk factors such as high phosphate enhances ADAMTS7 expression, producing COMP degradation, upregulating bone morphogenetic protein-2 (BMP-2) osteogenic signaling in VSMCs and, ultimately, accelerating vascular calcification ${ }^{[30]}$. COMP or thrombospondin-5 is abundant in the vasculature $^{[1]]}$. COMP is a major substrate of ADAMTS7, reduces calcification of vascular smooth muscle by inhibiting BMP-2 osteogenic signaling ${ }^{[31]}$. The concept of ADAMTS7 as a regulator of the amount of COMP suggests that ADAMTS7 polymorphisms associated with greater ADMTS7 activity will reduce the ability of COMP to oppose vascular calcification and permit calcification to proceed ${ }^{[30]}$.

The amount of CAC is a reflection of the underlying burden of atherosclerosis in coronary arteries and the presence of CAC is a prognostic marker for adverse outcome from coronary artery disease ${ }^{[29]}$. The association of ADAMTS7 polymorphism with CAC supports a linkage of ADAMTS7 with CAD pathogenesis.

\section{Coronary artery atherosclerosis}

The significant relationship of ADAMTS7 to coronary atherosclerosis is part of its general effect on atherosclerosis. ADAMTS7 is related to peripheral artery disease (PAD). ADAMTS7 polymorphism specifically rs1994016 and rs3825807 polymorphisms is associated with PAD ${ }^{[32]}$. ADAMTS7 mRNA levels were significantly increased for the CC genotype of rs1994016 and TT genotype of rs3825807 $7^{[32]}$. Pu et al..$^{[14]}$ reported an association between ADAMTS7 variation and carotid artery atherosclerosis in an Italian population cohort, with the rs3825807 G/G genotype which was associating with lower atherosclerosis prevalence and severity. Matrix metalloproteinases can have a profound effect on the vessel wall ${ }^{[33]}$. Metalloproteases play various roles in atherosclerotic plaque formation including vascular smooth muscle cell migration and plaque instability ${ }^{[34]}$.

The relationship of ADAMTS7 and coronary atherosclerosis is more than a simple association but rather ADAMTS7 correlates with the severity of CAD. The GG allele of rs3825807 conferred a $16 \%$ lower rate of coronary artery disease, $15 \%$ lower rate of multivessel coronary artery disease and a $17 \%$ lower rate of LAD disease $^{[18]}$. In addition, the rs3825807 was associated with less severe CAD as reflected in lower Gensini and lower Sullivan scores which quantitate the extent and severity of $\mathrm{CAD}^{[18]}$. Genetic changes in ADAMTS7 are presumably translated into changes in protein secretion and increases in circulating levels. Plasma ADAMTS7 levels are significantly higher in patients with more severe coronary artery disease Plasma ADAMTS7 levels were significantly and positively correlated with the severity of coronary artery disease as reflected by the Syntax score even in multivariate analysis ${ }^{[35]}$. ADAMTS7 level may be responsible, in part, for the severity of CAD.

The association of ADAMTS7 and CAD severity can be supported by long term prognostic studies as patients with more severe CAD have poorer prognosis. Genotyping for rs3825807 polymorphism show that the AA genotype is an independent risk factor for CV mortality compared with reference genotype $\mathrm{GG}^{[28]}$. Similar data was identified in a another cohort as survival was best for GG genotype, worst for the AA genotype and intermediate for the AG genotype ${ }^{[18]}$. 
Prognosis is in part determined by the nature of the coronary plaque and its probability of progression or rupture. The nature of the coronary plaque varies according to ADAMTS7 polymorphism. There was a significant association between the rs3825807 G allele and reduced fibrous cap thickness, reduced fibrous cap-to-intima thickness and a lower percentage area of $\alpha$-actin in intima ${ }^{[18]}$.

The interaction of genes and environment have produced the interesting observation that Allelic variations at rs7178051 that are associated with reduced ADAMTS7 expression confers CAD protection which is stronger in never-smokers than in cigarette smokers ${ }^{[36]}$. Enhanced vascular ADAMTS7 expression may lead to the loss of protection from CAD which occurs in cigarette smokers leading to the suggestion that inhibition of ADAMTS7 maybe especial helpful for individuals who smoke cigarettes ${ }^{[36]}$.

The mechanism by which ADAMTS7 produced coronary atherosclerotic narrowing is not fully delineated but there are several explanations. ADAMTS7 may impair the ability of the endothelium to undergo a normal repair process after injury because ADAMTS7 deficiency promoted re-endothelialisation after endothelial injury ${ }^{[37]}$. Animal data support the postulate that ADAMTS7 cleavage of TSP5 facilitates vascular smooth muscle cell migration and promotes neointimal formation which leads to $\mathrm{CAD}^{[13-15]}$. In vitro assays show that VSMCs of the G/G genotype have reduced migratory ability and produce fewercleaved product of the ADAMTS7 substrate TSP $5^{[14]}$. The Ser-to-Pro substitution has been postulated to reduce the accessibility to process proteases because the conformational change induced by the rigidity of Ser-to-Pro substitution leads to changes in ADAMTS7 maturation, TSP5 cleavage, and VSMC migration leading to atherosclerosis ${ }^{[14]}$.

ADAMTS7 localizes to smooth muscle cells in human coronary artery disease lesions, with a subcellular localization at the cytoplasm and cell membrane, where it co-localized with podosomes ${ }^{[15]}$. ADAMTS7 is proatherogenic as deletion of ADAMTS7 significantly reduces atherosclerotic lesion formation ${ }^{[15]}$. ADAMTS7 mediates vascular smooth muscle cell migration and neointima formation in ballooninjured rat arteries ${ }^{[13]}$. ADAMTS7 knockout mice show loss of neointima formation following vascular injury ${ }^{[15]}$. ADAMTS7 knockout mice had significant reductions in lesion formation in aortas and aortic roots and reduced neointimal formation after arterial injury ${ }^{[15]}$. ADAMTS7 knockout vascular smooth muscle cells showed reduced migration induced by in TNF alpha ${ }^{[15]}$. "Overfunctional" ADAMTS7 allele (A) may accelerate VSMC migration and producing neointimal thickening, accelerating atherosclerosis development leading to acute plaque events ${ }^{[28]}$.

In summary, ADAMTS7 is consistently related to human coronary artery disease as demonstrated by its association with both coronary artery calcification and coronary artery stenosis identified by coronary angiography. The ability of ADAMTS7 to produce degradation of the components of the vessel wall accelerates the process of atherosclerosis and prevents the normal repair of injured arteries. ADAMTS7 might represent a new target for drug development for the management of CAD.

\section{DECLARATIONS}

\section{Authors' contributions}

Wrote the majority of the manuscript and did some of the research: Rabkin SW

Wrote some of the manuscript and did the majority of the research: Koitsopoulos PG

\section{Data source and availability}

Data in this study were derived from searches of the PubMed database.

\section{Financial support and sponsorship}

None. 


\section{Conflicts of interest}

The authors declare no conflicts of interest.

\section{Patient consent}

Not applicable.

\section{Ethics approval}

Not applicable.

\section{Copyright}

(c) The Author(s) 2018.

\section{REFERENCES}

1. Gaziano TA, Bitton A, Anand S, Abrahams-Gessel S, Murphy A. Growing epidemic of coronary heart disease in low- and middleincome countries. Curr Probl Cardiol 2010;35:72-115.

2. Uthman OA, Hartley L, Rees K, Taylor F, Ebrahim S, Clarke A. Multiple risk factor interventions for primary prevention of CVD in LMIC: a cochrane review. Glob Heart 2017;12:199-208.e8.

3. Marenberg ME, Risch N, Berkman LF, Floderus B, de Faire U. Genetic susceptibility to death from coronary heart disease in a study of twins. N Engl J Med 1994;330:1041-6.

4. Schunkert H, König IR, Kathiresan S, Reilly MP, Assimes TL, Holm H, Preuss M, Stewart AF, Barbalic M, Gieger C, Absher D, Aherrahrou Z, Allayee H, Altshuler D, Anand SS, Andersen K, Anderson JL, Ardissino D, Ball SG, Balmforth AJ, Barnes TA, Becker DM, Becker LC, Berger K, Bis JC, Boekholdt SM, Boerwinkle E, Braund PS, Brown MJ, Burnett MS, Buysschaert I; Cardiogenics, Carlquist JF, Chen L, Cichon S, Codd V, Davies RW, Dedoussis G, Dehghan A, Demissie S, Devaney JM, Diemert P, Do R, Doering A, Eifert S, Mokhtari NE, Ellis SG, Elosua R, Engert JC, Epstein SE, de Faire U, Fischer M, Folsom AR, Freyer J, Gigante B, Girelli D, Gretarsdottir S, Gudnason V, Gulcher JR, Halperin E, Hammond N, Hazen SL, Hofman A, Horne BD, Illig T, Iribarren C, Jones GT, Jukema JW, Kaiser MA, Kaplan LM, Kastelein JJ, Khaw KT, Knowles JW, Kolovou G, Kong A, Laaksonen R, Lambrechts D, Leander K, Lettre G, Li M, Lieb W, Loley C, Lotery AJ, Mannucci PM, Maouche S, Martinelli N, McKeown PP, Meisinger C, Meitinger T, Melander O, Merlini PA, Mooser V, Morgan T, Mühleisen TW, Muhlestein JB, Münzel T, Musunuru K, Nahrstaedt J, Nelson CP, Nöthen MM, Olivieri O, Patel RS, Patterson CC, Peters A, Peyvandi F, Qu L, Quyyumi AA, Rader DJ, Rallidis LS, Rice C, Rosendaal FR, Rubin D, Salomaa V, Sampietro ML, Sandhu MS, Schadt E, Schäfer A, Schillert A, Schreiber S, Schrezenmeir J, Schwartz SM, Siscovick DS, Sivananthan M, Sivapalaratnam S, Smith A, Smith TB, Snoep JD, Soranzo N, Spertus JA, Stark K, Stirrups K, Stoll M, Tang WH, Tennstedt S, Thorgeirsson G, Thorleifsson G, Tomaszewski M, Uitterlinden AG, van Rij AM, Voight BF, Wareham NJ, Wells GA, Wichmann HE, Wild PS, Willenborg C, Witteman JC, Wright BJ, Ye S, Zeller T, Ziegler A, Cambien F, Goodall AH, Cupples LA, Quertermous T, März W, Hengstenberg C, Blankenberg S, Ouwehand WH, Hall AS, Deloukas P, Thompson JR, Stefansson K, Roberts R, Thorsteinsdottir U, O’Donnell CJ, McPherson R, Erdmann J; CARDIoGRAM Consortium; Samani NJ. Large-scale association analysis identifies 13 new susceptibility loci for coronary artery disease. Nat Genet 2011;43:333-8.

5. Nikpay M, Goel A, Won HH, Hall LM, Willenborg C, Kanoni S, Saleheen D, Kyriakou T, Nelson CP, Hopewell JC, Webb TR, Zeng L, Dehghan A, Alver M, Armasu SM, Auro K, Bjonnes A, Chasman DI, Chen S, Ford I, Franceschini N, Gieger C, Grace C, Gustafsson S, Huang J, Hwang SJ, Kim YK, Kleber ME, Lau KW, Lu X, Lu Y, Lyytikäinen LP, Mihailov E, Morrison AC, Pervjakova N, Qu L, Rose LM, Salfati E, Saxena R, Scholz M, Smith AV, Tikkanen E, Uitterlinden A, Yang X, Zhang W, Zhao W, de Andrade M, de Vries PS, van Zuydam NR, Anand SS, Bertram L, Beutner F, Dedoussis G, Frossard P, Gauguier D, Goodall AH, Gottesman O, Haber M, Han BG, Huang J, Jalilzadeh S, Kessler T, König IR, Lannfelt L, Lieb W, Lind L, Lindgren CM, Lokki ML, Magnusson PK, Mallick NH, Mehra N, Meitinger T, Memon FU, Morris AP, Nieminen MS, Pedersen NL, Peters A, Rallidis LS, Rasheed A, Samuel M, Shah SH, Sinisalo J, Stirrups KE, Trompet S, Wang L, Zaman KS, Ardissino D, Boerwinkle E, Borecki IB, Bottinger EP, Buring JE, Chambers JC, Collins R, Cupples LA, Danesh J, Demuth I, Elosua R, Epstein SE, Esko T, Feitosa MF, Franco OH, Franzosi MG, Granger CB, Gu D, Gudnason V, Hall AS, Hamsten A, Harris TB, Hazen SL, Hengstenberg C, Hofman A, Ingelsson E, Iribarren C, Jukema JW, Karhunen PJ, Kim BJ, Kooner JS, Kullo IJ, Lehtimäki T, Loos RJF, Melander O, Metspalu A, März W, Palmer CN, Perola M,Quertermous T, Rader DJ, Ridker PM, Ripatti S, Roberts R, Salomaa V, Sanghera DK, Schwartz SM, Seedorf U, Stewart AF, Stott DJ, Thiery J, Zalloua PA, O’Donnell CJ, Reilly MP, Assimes TL, Thompson JR, Erdmann J, Clarke R, Watkins H, Kathiresan S, McPherson R, Deloukas P, Schunkert H, Samani NJ, Farrall M. A comprehensive 1,000 genomes-based genome-wide association meta-analysis of coronary artery disease. Nat Genet 2015;47:1121-30.

6. Assimes TL, Roberts R. Genetics: implications for prevention and management of coronary artery disease. J Am Coll Cardiol 2016;68:2797-818.

7. ADAMTS7. Available from: https://www.ncbi.nlm.nih.gov/gene/11173 [Last accessed on 22 Mar 2018]

8. Hurskainen TL, Hirohata S, Seldin MF, Apte SS. ADAM-TS5, ADAM-TS6, and ADAM-TS7, novel members of a new family of zinc metalloproteases. General features and genomic distribution of the ADAM-TS family. J Biol Chem 1999;274:25555-63.

9. Hanby HA, Zheng XL. Biochemistry and physiological functions of ADAMTS7 metalloprotease. Adv Biochem 2013;1:11. 
10. Lu C. ADAMTS7. In: Rawlings ND, Salvesen G, editors. Handbook of Proteolytic Enzymes, Third Edition. Academic Press; 2013. p. 1180-6.

11. Fu Y, Kong W. Cartilage oligomeric matrix protein: matricellular and matricrine signaling in cardiovascular homeostasis and disease. Curr Vasc Pharmacol 2017;15:186-96.

12. Somerville RPT, Longpré JM, Apel ED, Lewis RM, Wang LW, Sanes JR, Leduc R, Apte SS. ADAMTS7B, the full-length product of the ADAMTS7 gene, is a chondroitin sulfate proteoglycan containing a mucin domain. $J$ Biol Chem 2004;279:35159-75.

13. Wang L, Zheng J, Bai X, Liu B, Liu CJ, Xu Q, Zhu Y, Wang N, Kong W, Wang X. ADAMTS-7 mediates vascular smooth muscle cell migration and neointima formation in balloon-injured rat arteries. Circ Res 2009;104:688-98.

14. Pu X, Xiao Q, Kiechl S, Chan K, Ng FL, Gor S, Poston RN, Fang C, Patel A, Senver EC, Shaw-Hawkins S, Willeit J, Liu C, Zhu J, Tucker AT, Xu Q, Caulfield MJ, Ye S. ADAMTS7 cleavage and vascular smooth muscle cell migration is affected by a coronary-arterydisease-associated variant. Am J Hum Genet 2013;92:366-74.

15. Bauer RC, Tohyama J, Cui J, Cheng L, Yang J, Zhang X, Ou K, Paschos GK, Zheng XL, Parmacek MS, Rader DJ, Reilly MP. Knockout of Adamts7, a novel coronary artery disease locus in humans, reduces atherosclerosis in mice. Circulation 2015;131:1202-13.

16. Review Manager (RevMan) [Computer program]. Version 5.3. Copenhagen: The Nordic Cochrane Centre, The Cochrane Collaboration. 2014.

17. Moher D, Liberati A, Tetzlaff J, Altman DG; PRISMA Group. Preferred reporting items for systematic reviews and meta-analyses: the PRISMA statement. PLoS Med 2009;6:e1000097.

18. Chan K, Pu X, Sandesara P, Poston RN, Simpson IA, Quyyumi AA, Ye S, Patel RS. Genetic variation at the ADAMTS7 locus is associated with reduced severity of coronary artery disease. J Am Hear Assoc 2017;6:e006928.

19. You L, Tan L, Liu L, Shen R, Chaugai S, Wang DW, Cui W. ADAMTS7 locus confers high cross-race risk for development of coronary atheromatous plaque. Mol Genet Genomics 2016;291:121-8.

20. Assimes TL, Lee IT, Juang JM, Guo X, Wang TD, Kim ET, Lee WJ, Absher D, Chiu YF, Hsu CC, Chuang LM, Quertermous T, Hsiung CA, Rotter JI, Sheu WH, Chen YD, Taylor KD. Genetics of coronary artery disease in Taiwan: a cardiometabochip study by the Taichi Consortium. PLoS One 2016;11:e0138014.

21. Lu X, Wang L, Chen S, He L, Yang X, Shi Y, Cheng J, Zhang L, Gu CC, Huang J, Wu T, Ma Y, Li J, Cao J, Chen J, Ge D, Fan Z, Li Y, Zhao L, Li H, Zhou X, Chen L, Liu D, Chen J, Duan X, Hao Y, Wang L, Lu F, Liu Z, Yao C, Shen C, Pu X, Yu L, Fang X, Xu L, Mu J, Wu X, Zheng R, Wu N, Zhao Q, Li Y, Liu X, Wang M, Yu D, Hu D, Ji X, Guo D, Sun D, Wang Q, Yang Y, Liu F, Mao Q, Liang X, Ji J, Chen P, Mo X, Li D, Chai G, Tang Y, Li X, Du Z, Liu X, Dou C, Yang Z, Meng Q, Wang D, Wang R, Yang J, Schunkert H, Samani NJ, Kathiresan S, Reilly MP, Erdmann J; Coronary ARtery DIsease Genome-Wide Replication And Meta-Analysis (CARDIoGRAM) Consortium; Peng X, Wu X, Liu D, Yang Y, Chen R, Qiang B, Gu D. Genome-wide association study in Han Chinese identifies four new susceptibility loci for coronary artery disease. Nat Genet 2012;44:890-4.

22. Dechamethakun S, Ikeda S, Arai T, Sato N, Sawabe M, Muramatsu M. Associations between the CDKN2A/B, ADTRP and PDGFD polymorphisms and the development of coronary atherosclerosis in Japanese patients. $J$ Atheroscler Thromb 2014;21:680-90.

23. Coronary Artery Disease (CAD) Genetic Consortium. A genome-wide association study in Europeans and South Asians identifies five new loci for coronary artery disease. Nat Genet 2011;43:339-44.

24. Reilly MP, Li M, He J, Ferguson JF, Stylianou IM, Mehta NN, Burnett MS, Devaney JM, Knouff CW, Thompson JR, Horne BD, Stewart AF, Assimes TL, Wild PS, Allayee H, Nitschke PL, Patel RS; Myocardial Infarction Genetics Consortium; Wellcome Trust Case Control Consortium; Martinelli N, Girelli D, Quyyumi AA, Anderson JL, Erdmann J, Hall AS, Schunkert H, Quertermous T, Blankenberg S, Hazen SL, Roberts R, Kathiresan S, Samani NJ, Epstein SE, Rader DJ. Identification of ADAMTS7 as a novel locus for coronary atherosclerosis and association of $\mathrm{ABO}$ with myocardial infarction in the presence of coronary atherosclerosis: two genomewide association studies. Lancet 2011;377:383-92.

25. Vargas JD, Manichaikul A, Wang XQ, Rich SS, Rotter JI, Post WS, Polak JF, Budoff MJ, Bluemke DA. Common genetic variants and subclinical atherosclerosis: the Multi-Ethnic Study of Atherosclerosis (MESA). Atherosclerosis 2016;245:230-6.

26. van Setten J, Isgum I, Smolonska J, Ripke S, de Jong PA, Oudkerk M, de Koning H, Lammers JW, Zanen P, Groen HJ, Boezen HM, Postma DS, Wijmenga C, Viergever MA, Mali WP, de Bakker PI. Genome-wide association study of coronary and aortic calcification implicates risk loci for coronary artery disease and myocardial infarction. Atherosclerosis 2013;228:400-5.

27. O’Donnell CJ, Kavousi M, Smith AV, Kardia SL, Feitosa MF, Hwang SJ, Sun YV, Province MA, Aspelund T, Dehghan A, Hoffmann U, Bielak LF, Zhang Q, Eiriksdottir G, van Duijn CM, Fox CS, de Andrade M, Kraja AT, Sigurdsson S, Elias-Smale SE, Murabito JM, Launer LJ, van der Lugt A, Kathiresan S; CARDIoGRAM Consortium; Krestin GP, Herrington DM, Howard TD, Liu Y, Post W, Mitchell BD, O'Connell JR, Shen H, Shuldiner AR, Altshuler D, Elosua R, Salomaa V, Schwartz SM, Siscovick DS, Voight BF, Bis JC, Glazer NL, Psaty BM, Boerwinkle E, Heiss G, Blankenberg S, Zeller T, Wild PS, Schnabel RB, Schillert A, Ziegler A, Münzel TF, White CC, Rotter JI, Nalls M, Oudkerk M, Johnson AD, Newman AB, Uitterlinden AG, Massaro JM, Cunningham J, Harris TB, Hofman A, Peyser PA, Borecki IB, Cupples LA, Gudnason V, Witteman JC. Genome-wide association study for coronary artery calcification with follow-up in myocardial infarction. Circulation 2011;124:2855-64.

28. Pereira A, Palma Dos Reis R, Rodrigues R, Sousa AC, Gomes S, Borges S, Ornelas I, Freitas AI, Guerra G, Henriques E, Rodrigues M, Freitas S, Freitas C, Brehm A, Pereira D, Mendonça MI. Association of ADAMTS7 gene polymorphism with cardiovascular survival in coronary artery disease. Physiol Genomics 2016;48:810-5.

29. Wexler L, Brundage B, Crouse J, Detrano R, Fuster V, Maddahi J, Rumberger J, Stanford W, White R, Taubert K. Coronary artery calcification: pathophysiology, epidemiology, imaging methods, and clinical implications. A statement for health professionals from the American Heart Association. Writing Group. Circulation 1996;94:1175-92. 
30. Du Y, Gao C, Liu Z, Wang L, Liu B, He F, Zhang T, Wang Y, Wang X, Xu M, Luo GZ, Zhu Y, Xu Q, Wang X, Kong W. Upregulation of a disintegrin and metalloproteinase with thrombospondin motifs-7 by miR-29 repression mediates vascular smooth muscle calcification. Arterioscler Thromb Vasc Biol 2012;32:2580-8.

31. Du Y, Wang Y, Wang L, Liu B, Tian Q, Liu CJ, Zhang T, Xu Q, Zhu Y, Ake O, Qi Y, Tang C, Kong W, Wang X. Cartilage oligomeric matrix protein inhibits vascular smooth muscle calcification by interacting with bone morphogenetic protein-2. Circ Res 2011;108:91728.

32. Bayoglu B, Arslan C, Tel C, Ulutin T, Dirican A, Deser SB, Cengiz M. Genetic variants rs1994016 and rs3825807 in ADAMTS7 affect its mRNA expression in atherosclerotic occlusive peripheral arterial disease. J Clin Lab Anal 2018;32:22174.

33. Rabkin SW. The role matrix metalloproteinases in the production of aortic aneurysm. Prog Mol Biol Transl Sci 2017;147:239-65.

34. Mittal B, Mishra A, Srivastava A, Kumar S, Garg N. Matrix metalloproteinases in coronary artery disease. Adv Clin Chem 2014;64:172.

35. Yu J, Zhou B, Yu H, Han J, Cui M, Zhang F, Wang G, Guo L, Gao W. Association between plasma ADAMTS-7 levels and severity of disease in patients with stable obstructive coronary artery disease. Medicine (Baltimore) 2016;95:e5523.

36. Saleheen D, Zhao W, Young R, Nelson CP, Ho W, Ferguson JF, Rasheed A, Ou K, Nurnberg ST, Bauer RC, Goel A, Do R, Stewart AFR, Hartiala J, Zhang W, Thorleifsson G, Strawbridge RJ, Sinisalo J, Kanoni S, Sedaghat S, Marouli E, Kristiansson K, Hua Zhao J, Scott R, Gauguier D, Shah SH, Smith AV, van Zuydam N, Cox AJ, Willenborg C, Kessler T, Zeng L, Province MA, Ganna A, Lind L, Pedersen NL, White CC, Joensuu A, Edi Kleber M, Hall AS, März W, Salomaa V, O’Donnell C, Ingelsson E, Feitosa MF, Erdmann J, Bowden DW, Palmer CNA, Gudnason V, Faire U, Zalloua P, Wareham N, Thompson JR, Kuulasmaa K, Dedoussis G, Perola M, Dehghan A, Chambers JC, Kooner J, Allayee H, Deloukas P, McPherson R, Stefansson K, Schunkert H, Kathiresan S, Farrall M, Marcel Frossard P, Rader DJ, Samani NJ, Reilly MP. Loss of cardioprotective effects at the ADAMTS7 locus as a result of gene-smoking interactions. Circulation 2017;135:2336-53.

37. Kessler T, Zhang L, Liu Z, Yin X, Huang Y, Wang Y, Fu Y, Mayr M, Ge Q, Xu Q, Zhu Y, Wang X, Schmidt K, de Wit C, Erdmann J, Schunkert H, Aherrahrou Z, Kong W. ADAMTS-7 inhibits re-endothelialization of injured arteries and promotes vascular remodeling through cleavage of thrombospondin-1. Circulation 2015;131:1191-201. 